\title{
Analisis Hubungan Dinamis Pertumbuhan Ekonomi dan Ketimpangan Pendapatan Indonesia Menggunakan Clustering dan Model Ekonometrik
}

Dara Purnama Kessyi

Politeknik Statistika STIS, 211709608@stis.ac.id

Dhofirur Rohmanu Romadhoni

Politeknik Statistika STIS, 211709623@stis.ac.id

Fadhila Annisa Maksum

Politeknik Statistika STIS, 211709672@stis.ac.id

Lita Nur Azizahiv

Politeknik Statistika STIS, $211709791 @$ @tis.ac.id
ABSTRAK, Barro (2000) menyatakan bahwa tidak ada hubungan yang signifikan antara pertumuhan ekonomi dan ketimpangan pendapatan di negara berkembang dengan penghasilan rendah. Hal yang berbeda justru ditunjukkan pada penelitian yang dilakukan di meksiko oleh Ortega (2006) yang menyatakan bahwa terdapat hubungan positif antara pertumuhan ekonomi dan ketimpangan pendapatan. Mempertimbangkan terkait perbedaan kesimpulan beberapa penelitian terkait hubungan pertumbuhan ekonomi dan ketimpangan pendapatan tersebut, maka dalam hal ini perlu kajian lebih mendalam untuk mengetahui hubungan keduanya khususnya di Indonesia.Tujuan dari penelitian ini adalah untuk menganalisis terkait hubungan antara pertumbuhan ekonomi dan ketimpangan pendapatan akan di Indonesia dengan terlebih dahulu melakukan pengelompokan (clustering) pada provinsi-provinsi yang ada berdasarkan karakteristik pertumuhan ekonomi dan ketimpangan pendapatanya. Metode pengklasteran yang digunakan adalah K-Means, K-Medoid, dan Fuzzy K-Means Medoid Noise. Yang selanjutnya akan dilakukan dengan uji kausalitas seta pengujian ekonometrik menggunakan ARDL. Didapatkan hasilklaster yang terbentuk ada 2 yaitu klaster 1 dengan kombinasi pertumbuhan ekonomi dan ketimpangan pendapatan yang rendah dan klaster 2 dengan kombinasi pertumbuhan ekonomi dan ketimpangan yang tinggi. Dari masing-masing klaster ini dilakukan analisis kausalitas dan ekonometrik. Didapatkan hasil pada klaster 1 ketimpangan pendapatan berpengaruh secara negatif signifikan terhadap pertumbuhan ekonomi pada jangka panjang maupun jangka pendek. Sedangkan pada klaster 2 pertumbuhan ekonomi berpengaruh secara positif signifikan terhadap ketimpangan pendapatan pada jangka panjang serta pada jangka pendek hanya dipengaruhi secara signifikan oleh nilai masa lalu dari ketimpangan pendapatan.

Kata Kunci: Clustering, K-Means, Economic Growth

\section{PENDAHULUAN}

Kesuksesan perekonomian suatu negara dapat dilihat dari seberapa besar hasil perekonomiannya telah dapat mewujudkan pemerataan kesejahteraan bagi seluruh wilayah yang ada. Hal ini berkaitan erat dengan kondisi ketimpangan pendapatan dan pertumbuhan ekonomi negara itu sendiri. Hal inilah yang menarik Piketti (2014) untuk meneliti terkait hubungan keduanya. Jika melihat Indonesia yang merupakan negara berkembang dengan persebaran wilayah yang cukup luas dan perbedaan karakteristik yang ada kajian untuk memahami hubungan antara pertumbuhan ekonomi dan ketimpangan pendapatan merupakan hal yang tidaklah mudah.

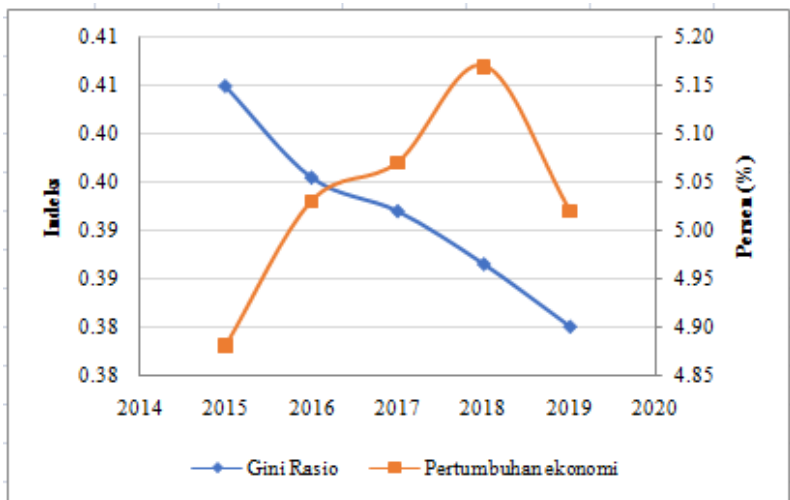

Gambar 1. Perkembangan Pertumbuhan Ekonomi dan Ketimpangan Indonesia Tahun 2015-2019

Sumber : BPS (2019)

Secara umum perkembangan pertumbuhan ekonomi Indonesia selama lima tahun terakhir mengalami peningkatan meskipun pada tahun 2019 mengalami penurunan dibanding tahun 2018 yaitu dari $5,17 \%$ menjadi $5,02 \%$. Perkembangan pertumbuhan ekonomi yang positif ini juga diiringi oleh pekembangan ketimpangan pendapatan yang mengalami penurunan. Telihat dari perkembangan gini rasio 
lima tahun terakhir Indonesia selalu mengalami penurunan dari angka 0,405 di tahun 2015 menjadi 0,38 di tahun 2019. Hal ini secara umum menunjukkan bahwa perkembangan pertumbuhan ekonomi di Indonesia berhasil menurunkan ketimpangan pendapatan yang ada.

Melihat lebih jauh mengenai fakta bahwa perkembangan pertumbuhan ekonomi di Indonesia berhasil menurunkan ketimpangan pendapatan yang ada, hal tersebut belum benarbenar terjadi. Wibowo (2016) menyatakan bahwa suksesnya pembangunan yang terlihat dari tingginya pertumbuhan ekonomi belum dinikmati secara merata di Indonesia. Kondisi ini dapat dibuktikan dari persebaran nilai pertumbuhan ekonomi di berbagai provinsi di Indonesia. Sebagian besar wilayah Indonesia timur mengalami penurunan pertumbuhan ekonomi jika dibandingkan dengan wilayah Indonesia bagian Barat pada tahun 2019. Selain itu beberapa willayah dengan penurunan pertumbuhan ekonomi memiliki nilai gini rasio yang tinggi. Misalnya provinsi Bangka Belitung yang mengalami penurunan pertumbuhan ekonomi pada tahun 2019 dengan nilai pertumuhan ekonomi terendah ke 3 yaitu sebesar 3,32\% merupakan provinsi dengan nilai gini rasio terendah dibandingkan provinsi lain yaitu sebesar 0,262. Hal serupa terjadi yaitu kondisi peningkatan pertumbuhan ekonomi yang diikuti peningkatan nilai gini rasio. Misalnya provini DIY yang mengalami peningkatan pertumuhan eknomi pada tahun 2019 dengan nilai pertumuhan ekonomi tertinggi ke 2 yaitu sebesar $6,6 \%$ merupakan provinsi dengan nilai gini rasio tertinggi dibandingkan provinsi lain yaitu sebesar 0,428 . Beberapa penelitian empiris menunjukkan kesimpulan yang memang berbeda pada hasil penelitian mereka mengenai hubungan antara ketimpangan pendapatan dan pertumbuhan ekonomi. Castello (2010) mengungkapkan bahwa pertumbuhan ekonomi dan ketimpagan pendapatan memiliki hubungan yang negatif di negara berkembang dengan penghasilan rendah. Hasil penelitian tersebut sejalan dengan temuan Agusalim (2016) yang mengungkapkan bahwa pertumbuhan ekonomi berpengaruh negatif terhadap ketimpangan pendapatan di Indonesia. Selanjutnya Barro (2000) menyatakan bahwa tidak ada hubungan yang signifikan antara pertumuhan ekonomi dan ketimpangan pendapatan di negara berkembang dengan penghasilan rendah. Hal yang berbeda justru ditunjukkan pada penelitian yang dilakukan di Meksiko oleh Ortega (2006) yang menyatakan bahwa terdapat hubungan positif antara pertumuhan ekonomi dan ketimpangan pendapatan.

Mempertimbangkan terkait perbedaan kesimpulan beberapa penelitian terkait hubungan pertumbuhan ekonomi dan ketimpangan pendapatan tersebut, maka dalam hal ini perlu kajian lebih mendalam untuk mengetahui hubungan keduanya khususnya di Indonesia. Alasan selanjutnya yaitu terkait perkembangan pertumbuhan ekonomi dan ketimpangan pendapatan dibeberapa provinsi di Indonesiaternuyata tidak sejalan dengan perkembangan kondisi nasional secara umum. Oleh sebab itu peneliti tertarik untuk menganalisis terkait hubungan antara pertumbuhan ekonomi dan ketimpangan pendapatan akan di Indonesiadengan terlebih dahulu melakukan pengelompokan (clustering) pada provinsi-provinsi yang ada berdasarkan karakteristik pertumuhan ekonomi dan ketimpangan pendapatanya. Dari hasil pengelompokan yang telah dilakukan akan dikaji mengenai hubungan antara pertumbuhan ekonomi dan ketimpangan pendapatan pada masing-masing kelompok. Langkah ini diharapkan dapat menjawab tujuan penelitiaan dalam hal ini untuk mengetahui hubungan pertumbuhan ekonomi dan ketimpangan pendapatan berdasarkan karakteristik provinsi yang ada di Indonesia.

\section{TINJAUANPUSTAKA}

\section{Clustering type 1}

Clustering tipe 1 digunakan untuk melihat secara gambaran mengenai perkembangan provinsi Indonesia terhadap 2 variabel tersebut selama periode 2001-2019. Tahap ini diawali dengandibentuk clustering dengan membagi provinsi - provinsi di Indonesia menjadi empat klaster berdasarkan pada rata - rata tahunan PDRB per kapita $\left(\boldsymbol{\mu}_{\boldsymbol{y}}\right)$ dan rata - rata tahunan gini rasio $\left(\boldsymbol{\mu}_{\boldsymbol{g}}\right)$. Hal ini sejalan dengan penelitian Brida et al (2020) yang meneliti tentang 
Perubahan Struktural dan Dinamika Ekonomi menggunakan metode klastering yang juga mempartisi negara - negara berdasarkan rezim untuk menangkap secara kualitatif dari sistem yang dinamis atau situasi kinerja ekonomik yang secara kualitatif berbeda dari yang lain dengan berdasarkan rata - rata pertumbuhan PDRB per kapita dan indeks gini. Pembagian provinsi provinsi di Indonesia menjadi empat klaster dengan rincian sebagai berikut.

$$
\begin{array}{cl}
\text { i. } & \left.C_{1}=\left\{(\mathbf{y}, \mathbf{g}): \mathbf{g} \geq \boldsymbol{\mu}_{\boldsymbol{g}}, \mathbf{y} \leq \boldsymbol{\mu}_{\boldsymbol{y}}\right)\right\} \\
\text { ii. } & \left.C_{2}=\left\{(\mathbf{y}, \mathbf{g}): \mathbf{g} \geq \boldsymbol{\mu}_{\boldsymbol{g}}, \mathbf{y} \geq \boldsymbol{\mu}_{\boldsymbol{y}}\right)\right\} \\
\text { iii. } & \left.C_{3}=\left\{(\mathbf{y}, \mathbf{g}): \mathbf{g} \leq \boldsymbol{\mu}_{\boldsymbol{g}}, \mathbf{y} \geq \boldsymbol{\mu}_{\boldsymbol{y}}\right)\right\} \\
\text { iv. } & \left.C_{4}=\left\{(\mathbf{y}, \mathbf{g}): \mathbf{g} \leq \boldsymbol{\mu}_{\boldsymbol{g}}, \mathbf{y} \leq \boldsymbol{\mu}_{\boldsymbol{y}}\right)\right\}
\end{array}
$$

Klaster $1\left(C_{1}\right)$ adalah kelompok dengan tingkat pertumbuhan rendah dan ketimpangan tinggi. Klaster $2\left(C_{2}\right)$ adalah kelompok dengan tingkat pertumbuhan dan ketimpangan tinggi. Klaster $3\left(C_{3}\right)$ adalah kelompok dengan tingkat pertumbuhan tinggi dan ketimpangan rendah. Klaster $4\left(C_{4}\right)$ adalah kelompok dengan tingkat pertumbuhan dan ketimpangan rendah.

\section{Clustering type 2}

Setelah melakukan clustering tipe 2 dilanjutkan dengan clustering tahap kedua menggunakan metode klastering $K$-Means, $K$ Medoids dan Fuzz yK-Medoid With Noise (FKMMed-Noise).

\section{K-Means}

$K$-Means adalah pendekatan clustering yang berbasis pembagian dataset secara iteratif. Dataset akan dibagi ke beberapa non empty cluster (tidak ada klaster yang anggotanya kosong, minimal anggota satu). Pembagian dataset tersebut berdasarkan jarak terdekat dengan pusat klaster kelompok yang memiliki kesamaan karakteristik satu sama lain.

\section{K-Medoids}

K-Medoids atau Partitioning Around Medoids (PAM) adalah algoritma clustering yang mirip dengan $K$-Means. Perbedaan dari kedua algoritma ini yaitu algoritma $K$-Medoids atau PAM menggunakan objek sebagai perwakilan (Medoid) sebagai pusat cluster untuk setiap cluster, sedangkan $K$-Meansmenggunakan nilai rata-rata (mean) sebagai pusat cluster (Kaur, dkk., 2014).

\section{Fuzzy K-Medoids}

Metode Fuzzy $K$ - Medoids dapat mengatasi outlier pada suatu kumpulan data.
Dengan menerapkan teknik Medoid dapat diterapkan pada semua jenis data. Misal diberikan suatu himpunan data $X=$ $\left\{x_{1}, x_{2}, \ldots, x_{n}\right\}, x_{i} \in \mathbb{R}^{d}, i=1,2, \ldots, n, n \times c$ anggota dari matriks $\mathrm{U}=\left[u_{i j}\right], 1 \leq i \leq n, 1 \leq j \leq c$ dan $V=\left\{v_{1}, v_{2}, \ldots, v_{c}\right\} \subset \mathbb{R}^{d}$ adalah himpunan Medoid. Fungsi tujuan adalah :

$$
J(U, V)=\sum_{i}^{n} \sum_{j}^{c} u_{i j} u_{i j}{ }^{m} r\left(x_{i}, v_{j}\right)
$$

Krishnapuram dkk. (2001) menggunakan persamaan fungsi tujuan 1 untuk mengatasi masalah pencilan. Definisikan $r\left(x_{i}, v_{j}\right)$ sebagai fungsi ketidaksamaan antara $x_{i}$ dan prototipe $\boldsymbol{v}_{\boldsymbol{j}} \in V$. Derajat fuzziness (ketidakjelasan) dinotasikan dengan $m$ dimana $b=-\frac{1}{m-1}$. Untuk melakukan pembaruan keanggotaan menggunakan persamaan berikut.

$$
u_{i j}=\frac{r^{b}\left(x_{i}, v_{j}\right)}{\sum_{k=1}^{c} r^{b}\left(x_{i}, v_{j}\right)}, 1 i \leq n, 1 \leq j \leq c
$$

Algoritma Fuzzy K-Medoids terdiri dari,

1. Inisialisasi $V=\left\{v_{1}, v_{2}, \ldots, v_{c}\right\}$ dimana setiap $v_{j}, 1 \leq j \leq c$, berasal dari klaster berbeda.

2. Perbarui keanggotaan $u_{i j}$ menggunakan persamaan (2).

Perbarui Medoid $v_{j} \in V$ dengan $v_{j}=x_{p}$ dimana $1 \leq j \leq c$ dan $p=\arg \min u_{i j}{ }^{m} r\left(x_{q}, v_{i}\right)$

Dalam prakteknya ketiga metode clustering tersebut dapat dengan mudah dieksekusi menggunakan package yang ada di dalam software R antara lain package cluster dan package efclust. Untuk mengevaluasi mana klaster yang paling baik peneliti menggunakan index Dunn dan Silhoutte dikarenakan tidak ada metode evaluasi secara spesifik untuk pengklasteran. Sedangkan untuk nilai index dapat menggunakan package clvalid

\section{METODOLOGI}

Penelitian ini menggunakan data sekunder yang berasal dari Badan Pusat Statistik (BPS). Data yang digunakan adalah data 34 provinsi di Indonesia dengan rentang waktu selama 20 tahun, yaitu 2000 -2019. Data dalam penelitian ini terdiri dari data pertumbuhan ekonomi yang digambarkan oleh pertumbuhan PDRB Per Kapita dan data ketimpangan pendapatan yang digambarkan dengan Gini Rasio. 


\section{Prosedur Analisis}

Analisis hubungan pertumbuhan ekonomi dan ketimpangan pendapatan menggunakan kombinasi metode clustering dan ekonometrik. Berikut adalah langkah-langkah analisis yang dilakukan:

1. Melakukan prepocessing pada data

2. Membentuk cluster type I

3. Membentuk cluster type II

4. Melakukan evaluasi hasil cluster

5. Uji kausalitas menggunakan metode ekonometrik

\section{PEMBAHASAN}

\section{Data Prepocessing}

Data Prepocessing adalah tahapan yang dilakukan untuk membuat data mentah menjadi data yang baik (tidak memiliki missing value) sebelum dilakukan analisis. Adapun langkah langkah data prepocessing dalam penelitian ini adalah,

1. Delete Variabel, menghapus variabel yang tidak memiliki makna atau tidak diperlukan dalam perhitungan seperti kolom Indonesia dan kolom series tahun. Kolom Indonesia dihapus karena yang akan diteliti pada penelitian ini adalah provinsi-provinsi di Indonesia sehingga untuk Indonesia secara umum tidak diperlukan. Sementara kolom series tahun dihapus karena juga tidak diperlukan dalam penelitian ini.

2. Mengatasi Missing Value, merubah "." dengan NA dan melihat proporsi missing value dengan visualisasi data. Adapun visualisasi missing value pada variabel PDRB perkapita provinsi dan variabel gini rasio provinsi adalah sebagai berikut,
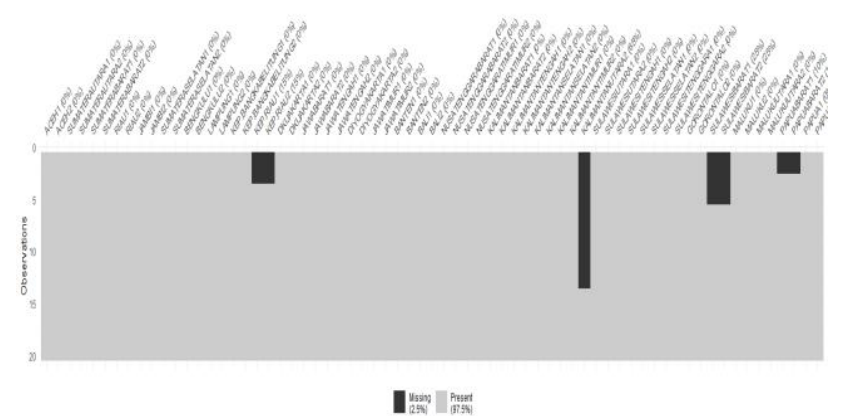

Gambar 2. Visualisasi missing value variabel PDRB perkapita provinsi
Pada gambar 2, terlihat bahwa ada missing value pada variabel PDRB per kapita untuk provinsi Kepulauan Riau, Kalimantan Utara, Sulawesi Barat, dan Papua Barat. Dengan total proporsi missing value sebesar $2,5 \%$.

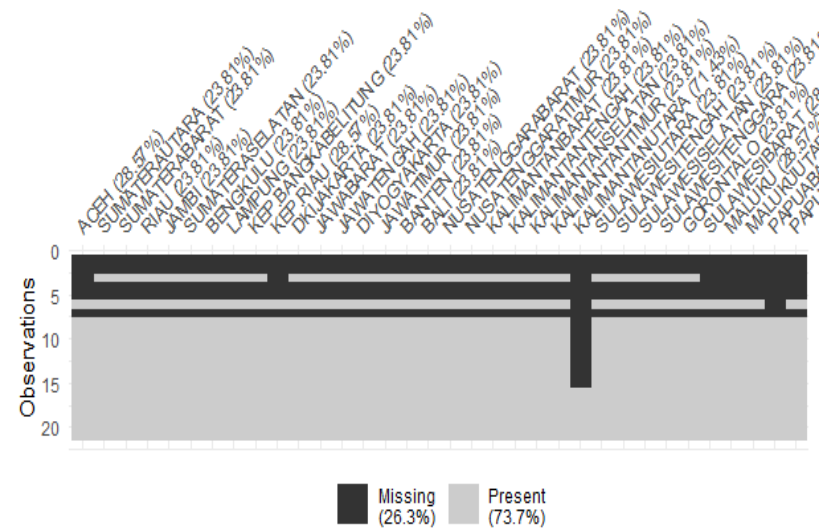

Gambar 3. Visualisasi missing value variabel Gini Rasio provinsi

Pada gambar 3, terlihat bahwa ada missing value pada variabel gini rasio untuk setiap provinsi dengan proporsi masing-masing. Total proporsi missing value pada variabel gini ratio ini adalah sebesar $26,3 \%$.

3. Transformasi tahap pertama, menyamakan tahun dasar (tahun dasar 2000 dan tahun dasar 2010). Pada penelitian ini terdapat dua data variabel PDRB per kapita dan gini rasio provinsi dengan dua tahun dasar berbeda. Tahun dasar 2000 untuk data series tahun 2000-2010 dan tahun dasar 2010 untuk data series tahun 2010-2019. Sehingga perlu dilakukannya transformasi data dengan menyamakan tahun dasar masing-masing ke tahun 2000 atau 2010.

4. Imputasi, mengatasi nilai yang kosong dengan dilakukan imputasi menggunakan mice dengan pertimbangan nilai mice pilihan rata-rata. Sehingga missing value pada variabel PDRB perkapita sebesar 2,5\% dan Gini rasio sebesar 26,3\% dapat terisi dengan imputasi ini.

5. Transformasi tahap kedua, merubah dalam bentuk growth untuk data pdrb perkapita tahun 2000 - 2019 dengan menggunakan tahun dasar 2010. Sehingga series data pada penelitian ini berubah menjadi series tahun 2001-2019.

Setelah dilakukan data prepocessing akan didapatkan data tanpa missing value dan periode 
data untuk analisis menjadi 2001-2019 karena didapat dari hasil perhitungan pertumbuhan PDRB per kapita provinsi di Indonesia.

\section{Hasil empiris clustering}

Pada clustering tipe 1 dihasilkan persentase masing-masing provinsi terklasifikasi pada masing-masing klaster berdasarkan data pada setiap periode tahunnya. Sehingga persentase klasterisasi masing-masing provinsi adalah sebagai berikut,

Tabel 4.1 Persentase klasterisasi masing-masing provinsi

\begin{tabular}{|c|c|c|c|c|}
\hline \multirow{2}{*}{ Provinsi } & \multicolumn{4}{|c|}{ Cluster } \\
\hline & R1 & R2 & R3 & $\mathrm{R} 4$ \\
\hline \multirow{3}{*}{ Aceh } & & & 16 & 26 \\
\hline & $5 \%$ & $53 \%$ & $\%$ & $\%$ \\
\hline & & & 21 & 47 \\
\hline \multirow[t]{2}{*}{ Sumatera Utara } & $11 \%$ & $21 \%$ & $\%$ & $\%$ \\
\hline & & & 26 & 32 \\
\hline \multirow{2}{*}{ Sumatera Barat } & $16 \%$ & $26 \%$ & $\%$ & $\%$ \\
\hline & & & 26 & 32 \\
\hline \multirow[t]{2}{*}{ Riau } & $16 \%$ & $26 \%$ & $\%$ & $\%$ \\
\hline & & & 26 & 16 \\
\hline \multirow[t]{2}{*}{ Jambi } & $26 \%$ & $32 \%$ & $\%$ & $\%$ \\
\hline & & & 21 & 32 \\
\hline \multirow[t]{2}{*}{ Sumatera Selatan } & $32 \%$ & $16 \%$ & $\%$ & $\%$ \\
\hline & & & 11 & 26 \\
\hline \multirow[t]{2}{*}{ Bengkulu } & $37 \%$ & $26 \%$ & $\%$ & $\%$ \\
\hline & & & 21 & 26 \\
\hline \multirow[t]{2}{*}{ Lampung } & $21 \%$ & $32 \%$ & $\%$ & $\%$ \\
\hline & & & 21 & 26 \\
\hline \multirow[t]{2}{*}{ Kep.Bangka Belitung } & $16 \%$ & $37 \%$ & $\%$ & $\%$ \\
\hline & & & 32 & 21 \\
\hline \multirow[t]{2}{*}{ Kep.riau } & $11 \%$ & $37 \%$ & $\%$ & $\%$ \\
\hline & & & 16 & 32 \\
\hline \multirow[t]{2}{*}{ DKI Jakarta } & $11 \%$ & $42 \%$ & $\%$ & $\%$ \\
\hline & & & 21 & 21 \\
\hline \multirow[t]{2}{*}{ Jawa Barat } & $21 \%$ & $37 \%$ & $\%$ & $\%$ \\
\hline & & & 26 & 11 \\
\hline \multirow[t]{2}{*}{ Jawa Tengah } & $42 \%$ & $21 \%$ & $\%$ & $\%$ \\
\hline & & & 11 & 32 \\
\hline \multirow[t]{2}{*}{ DI yogyakarta } & $16 \%$ & $42 \%$ & $\%$ & $\%$ \\
\hline & & & 26 & 21 \\
\hline \multirow[t]{2}{*}{ Jawa Timur } & $5 \%$ & $47 \%$ & $\%$ & $\%$ \\
\hline & & & 11 & 32 \\
\hline \multirow[t]{2}{*}{ Banten } & $37 \%$ & $21 \%$ & $\%$ & $\%$ \\
\hline & & & 11 & 32 \\
\hline \multirow[t]{2}{*}{ Bali } & $11 \%$ & $47 \%$ & $\%$ & $\%$ \\
\hline & & & 16 & 26 \\
\hline \multirow[t]{2}{*}{ Nusatenggara Barat } & $21 \%$ & $37 \%$ & $\%$ & $\%$ \\
\hline & & & 26 & \\
\hline \multirow[t]{2}{*}{ Nusatenggara Timur } & $26 \%$ & $42 \%$ & $\%$ & $5 \%$ \\
\hline & & & 16 & 53 \\
\hline \multirow[t]{2}{*}{ Kalimantan Barat } & $11 \%$ & $21 \%$ & $\%$ & $\%$ \\
\hline & & & 16 & 21 \\
\hline \multirow[t]{2}{*}{ Kalimantan Tengah } & $37 \%$ & $26 \%$ & $\%$ & $\%$ \\
\hline & & & 21 & 26 \\
\hline Kalimantan Selatan & $21 \%$ & $32 \%$ & $\%$ & $\%$ \\
\hline & & & 26 & 26 \\
\hline Kalimantan Timur & $21 \%$ & $26 \%$ & $\%$ & $\%$ \\
\hline
\end{tabular}

\begin{tabular}{lllll}
\hline \multirow{2}{*}{ Provinsi } & \multicolumn{4}{c}{ Cluster } \\
\cline { 2 - 5 } & $\mathrm{R} 1$ & $\mathrm{R} 2$ & $\mathrm{R} 3$ & $\mathrm{R} 4$ \\
\hline \multirow{2}{*}{ Kalimantan Utara } & $16 \%$ & $16 \%$ & $\%$ & $\%$ \\
Sulawesi Utara & $11 \%$ & $58 \%$ & $\%$ & $\%$ \\
Sulawesi Tengah & $21 \%$ & $32 \%$ & $\%$ & $\%$ \\
& & & 11 & 26 \\
Sulawesi Selatan & $11 \%$ & $53 \%$ & $\%$ & $\%$ \\
& & & 21 & 21 \\
Sulawesi Tenggara & $37 \%$ & $21 \%$ & $\%$ & $\%$ \\
& & & 21 & 16 \\
Gorontalo & $26 \%$ & $37 \%$ & $\%$ & $\%$ \\
& & & 21 & 21 \\
Sulawesi Barat & $42 \%$ & $16 \%$ & $\%$ & $\%$ \\
& & & 26 & 16 \\
Maluku & $5 \%$ & $53 \%$ & $\%$ & $\%$ \\
Maluku Utara & & & 32 & 16 \\
Papua Barat & $11 \%$ & $42 \%$ & $\%$ & $\%$ \\
Papua & & & 16 & 26 \\
& $53 \%$ & $5 \%$ & $\%$ & $\%$ \\
& & & 32 & 26 \\
\hline
\end{tabular}

\section{Sumber: BPS (diolah)}

Pada tabel 4.1, Provinsi Aceh paling banyak periode-nya terkelompok pada klaster 2 yaitu sebanyak 53\%, sehingga mayoritas Provinsi Aceh berada pada klaster 2 yaitu pertumbuhan ekonomi yang tinggi dan ketimpangan yang juga tinggi. Sementara Provinsi Sumatera Utara paling bayak periode-nya terkelompok pada klaster 4 yaitu sebanyak 47\%, sehingga mayoritas Provinsi Sumatera Utara berada pada klaster 4 yaitu pertumbuhan ekonomi yang rendah dan ketimpangan yang juga rendah. Begitu juga seterusnya untuk provinsi-provinsi lainnya.

Setelah melakukan clustering tipe 1 dilanjutkan dengan clustering tipe 2 menggunakan metode clustering data mining. Tujuan menggunakan pengklasteran dengan data mining adalah untuk menganalisis secara objektif menggunakan running pada software $R$. Pada tahap ini peneliti menggunakan try error dikarenakan kondisi data yang noise. Sehingga untuk mencapai hasil pengelompokan dengan 3 metode terakhir yaitu $K$-Means, $K$-Medoid, dan FKM Medoid noise peneliti menggunakan berbagai metode pengklasteran data mining mulai dari hierarki klaster hingganon hierarki klaster. Setelah dilakukan 3 tahapan uji coba dalam pengklasteran didapatkan hasil perbandingan 3 metode terakhir adalah yang terbaik dalam mempertimbangkan noise. Untuk mempersingkat pembahasan karena 2 tahapan 
sebelumnya adalah uji coba hanya disimpan untuk laporan hasil penelitian oleh peneliti.

Percobaan tahap terakhir pengklasteran type 2 dikerucutkan dengan menghilangkan metode hierarki karena adanya outlier akan menarik amatan ke klaster yang salah.Selain itu nilai indeks dunn dan silhoutte sebagai pertimbangan memiliki nilai yang lebih besar pada metode non hierarki dibanding metode hierarki menyebabkan analisis dikerucutkan menjadi 3 metode yaitu kmeans, kMedoid yaitu kmeans yang lebih robust dengan adanya outlier, dan Fuzzyclustering. Keterangan noise pada Fuzzyclustering adalah untuk melihat amatan mana yang memiliki membership yang terlalu berbeda dengan yang lain sehingga menjadi unclear (tidak jelas lokasi klasternya). Setelah dilakukan running didapatkan 5 provinsi dengan unclear membership).

Tabel 4.2 Perbandingan nilai Indeks Dunn dan Silhoutte pada masing-masing metode

\begin{tabular}{|c|c|c|c|c|}
\hline Method & $\begin{array}{c}\text { Cluster } \\
\text { opt }\end{array}$ & Dunn & Silhoutte & Provinsi \\
\hline Kmeans & 3 & 0.1052 & 0.4153 & $\begin{array}{rrrrrrrrrr}2 & 3 & 3 & 3 & 3 & 3 & 3 & 3 & 2 & 3 \\
1 & 1 & 3 & 1 & 3 & 1 & 3 & 3 & 3 & 3 \\
3 & 3 & 3 & 2 & 1 & 3 & 1 & 1 & 1 & 3 \\
& & & 3 & 3 & 1 & 1 & & & \\
1 & 2 & 2 & 2 & 2 & 2 & 2 & 2 & 1\end{array}$ \\
\hline $\begin{array}{c}K- \\
\text { Medoid }\end{array}$ & 3 & 0.0839 & 0.4168 & 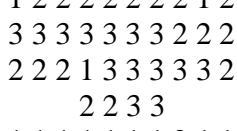 \\
\hline Fkm & 2 & 0.7555 & 0.5845 & 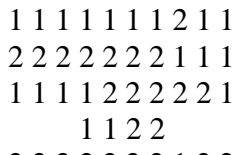 \\
\hline $\begin{array}{l}\text { FKM- } \\
\text { Medoid }\end{array}$ & 2 & 0.7555 & 0.5845 & $\begin{array}{llllllllll}2 & 2 & 2 & 2 & 2 & 2 & 2 & 1 & 2 & 2 \\
1 & 1 & 1 & 1 & 1 & 1 & 1 & 2 & 2 & 2 \\
2 & 2 & 2 & 2 & 1 & 1 & 1 & 1 & 1 & 2 \\
& & & & 2 & 2 & 1 & 1 & & \end{array}$ \\
\hline $\begin{array}{l}\text { FKM- } \\
\text { med- } \\
\text { noise }\end{array}$ & $2(5)$ & 0.7555 & 0.5845 & $\begin{array}{llllllllll}1 & 1 & 1 & 1 & 1 & 1 & 1 & 1 & 1 & 1 \\
2 & 2 & 2 & 2 & 2 & 2 & 2 & 1 & 1 & 1 \\
1 & 1 & 1 & 1 & 2 & 2 & 2 & 2 & 2 & 1 \\
& & & 1 & 1 & 2 & 2 & & & \\
\end{array}$ \\
\hline
\end{tabular}

Dari tabel 4.3 didapatkan hasil berdasarkan index Dunn dan Silhoutte dengan nilai tertinggi terletak pada metode fuzzy dengan klaster optimum berjumlah 2 klaster. Index yang dihasilkan oleh ketiga jenis metode fuzzy memiliki besar yang sama dan hasil pengklasteran yang sama juga. Peneliti memilih metode yang terbaik pada metode fuzzy ketiga yaitu FKM-med-noise dikarenakan metode tersebut menunjukkan mana provinsi yang berpotens menjadi noise dan berguna untuk pertimbangan lanjutan analisis ekonometrik

Tabel 4.3 Hasil percobaan Clustering tahap 3

\begin{tabular}{|c|}
\hline Cluster 1 (advance) \\
\hline $\begin{array}{l}\text { Aceh, Sumatera Utara, Sumatera Barat, Riau, Jambi, } \\
\text { Sumatera Selatan, Bengkulu, Lampung, Bangka } \\
\text { Belitung, Kepulauan Riau, NTB, NTT, Kalimantan } \\
\text { Utara, Kalimantan Barat, Kalimantan Tengah, } \\
\text { Kalimantan Selatan, Kalimantan Timur, Sulawesi } \\
\text { Barat, Maluku, Maluku Utara }\end{array}$ \\
\hline Cluster 2 (developing) \\
\hline $\begin{array}{l}\text { DKI Jakarta, Jawa Barat, Jawa Tengah, DI Yogyakarta, } \\
\text { Jawa Timur, Banten, Bali, Sulawesi Utara, Sulawesi } \\
\text { Tengah, Sulawesi Selatan, Sulawesi Tenggara, } \\
\text { Gorontalo, Papua Barat, Papua }\end{array}$ \\
\hline
\end{tabular}

Hasil dari clustering tipe 2 didapatkan provinsi yang berada pada klaster 1 (developing cluster) adalah klaster dengan anggotanya yang sering berada pada kondisi C3 dan C4 pada periode penelitian dan klaster 2 (advance cluster) adalah klaster dengan anggotanya yang sering berada pada kondisi $\mathrm{C} 1$ dan $\mathrm{C} 2$ atau bisa juga kedua klaster tersebut disebut dengan klaster dengan ketimpangan pendapatan yang rendah dan ketimpangan pendapatan yang tinggi. Akan tetapi hasil pengujian ini tidak bisa seutuhnya dibandingkan dengan clustering tipe 1 karena dasar logic yang dipakai sudah berbeda. Hasil dari clustering type 2 menggunakan teori derajat keanggotaan pada fuzzy. Sedangkan untuk clustering type 1 menggunakan perhitungan manual dengan excel. Sehingga didapatkan kesimpulan bahwa hasil klasternya dapat dibagi menjadi klaster 1 yaitu klaster dengan ketimpangan pendapatan yang rendah dan dan klaster 2 yaitu klaster dengan ketimpangan pendapatan yang tinggi

Sedangkan dengan untuk povinsi yang unclear diantaranya yaitu Provinsi Aceh, Bangka Belitung, Kalimantan Utara, DI Yogyakarta, dan Papua. Provinsi ini berupa pencilan, pencilan disini adalah pengelompokkan dengan periode tersebut belum mampu memutuskan pola ekonomi dari provinsi tersebut, selain itu kondisi provinsi baru seperti Kalimantan Utara juga menyebabkan belum mampunya memtuskan pola pengelompokkan, alasan lain adalah adanya ketimpangan yang terlalu tinggi seperti DI 
Yogyakarta dan provinsi yang sering mengalami inflasi atau kerusuhan seperti Papua. Setelah didapatkan hasil, klaster tersebut dilanjutkan analisisnya tanpa melibatkan pencilannya.

\section{Cluster Plot}

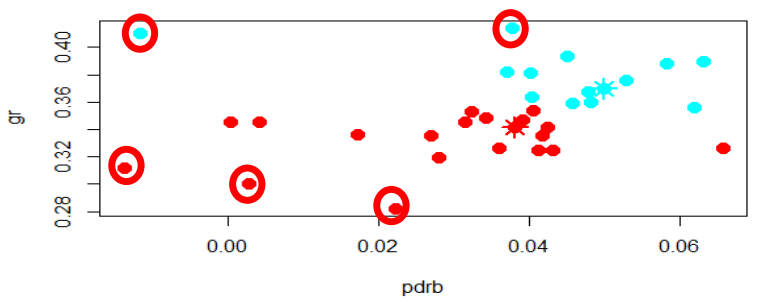

Gambar 4. Cluster Plot

Kelima plot yang dilingkari ialah provinsi outlier.

\section{Uji Kausalitas dan hasil analisis ekonometrik}

Uji kausalitas yang digunakan adalah uji kausalitas Granger. Uji ini dilakukan untuk melihat hubungan timbal balik antara variabel pertumbuhan PDRB perkapita dan variabel gini rasio pada masing masing klaster

Tabel 4.4 Hasil output uji kausalitas klaster 1

\begin{tabular}{lccc}
\hline \hline Null Hypothesis: & Obs & F-Statistic & Prob. \\
\hline \hline GR does not Granger Cause PDRB & 272 & 6.83633 & 0.0002 \\
PDRB does not Granger Cause GR & & 26.2386 & 7. E-15 \\
\hline \hline
\end{tabular}

Tabel 4.5 Hasil output uji kausalitas klaster 2

\begin{tabular}{lccc}
\hline \hline Null Hypothesis: & Obs & F-Statistic & Prob. \\
\hline \hline GR does not Granger Cause PDRB & 192 & 1.25591 & 0.2910 \\
PDRB does not Granger Cause GR & & 2.81765 & 0.0404 \\
\hline
\end{tabular}

Pada klaster 1 tolak $\mathrm{H}_{0}$ pada poin yang pertama yang berarti pada klaster 1 pertumbuhan ekonomi dipengaruhi oleh ketimpangan pendapatan. Sedangkan klaster 2 tolak $\mathrm{H}_{0}$ pada poin yang kedua yang berarti pada klaster 2 ketimpangan pendapatan dipengaruhi oleh pertumbuhan ekonomi

Dari klaster yang telah terbentuk pada tahap kedua dan hasil uji kausalitas, dibentuk model regresi menggunakan metode ARDL

Tabel 4.6 Hasil output ARDL

\begin{tabular}{|l|}
\hline Panel $\mathrm{C} 1$ \\
\hline Dependent variabel: $\Delta \mathrm{y}$ dynamics of economic growth \\
\hline $\begin{array}{l}\text { Dynamic regressor: Gini index }(\mathrm{g}), \text { Gini index } \\
\text { squared }\left(\mathrm{g}^{2}\right)\end{array}$ \\
\hline Selected Model: ARDL $(2,4,4)$ \\
\hline
\end{tabular}

\begin{tabular}{crrrr}
\hline \hline Variable & Coefficient & Std. Error & t-Statistic & Prob. $^{*}$ \\
\hline \hline \multicolumn{5}{c}{ Long Run Equation } \\
GR & -12.68656 & 1.156010 & -10.97444 & 0.0000 \\
GR2 & 19.10723 & 1.713203 & 11.15293 & 0.0000 \\
\hline \hline \multicolumn{5}{c}{ Short Run Equation } \\
COINTEQ01 & -0.328669 & 0.153178 & -2.145668 & 0.0337 \\
D(PDRB(-1)) & -0.071521 & 0.105271 & -0.679397 & 0.4981 \\
D(GR) & 13.47853 & 6.642533 & 2.029125 & 0.0444 \\
D(GR(-1)) & 2.461089 & 3.132406 & 0.785686 & 0.4334 \\
D(GR(-2)) & 1.290807 & 1.656872 & 0.779063 & 0.4373 \\
D(GR(-3)) & 2.626630 & 1.387548 & 1.893002 & 0.0605 \\
D(GR2) & -18.51497 & 8.950175 & -2.068672 & 0.0405 \\
D(GR2(-1)) & -3.790389 & 4.355572 & -0.870239 & 0.3857 \\
D(GR2(-2)) & -1.687242 & 2.434994 & -0.692914 & 0.4896 \\
D(GR2(-3)) & -3.753468 & 2.036440 & -1.843152 & 0.0675 \\
C & 0.697197 & 0.325654 & 2.140913 & 0.0341 \\
\hline \hline Mean dependent var & -0.001354 & S.D. dependent var & 0.054587 \\
S.E. of regression & 0.019380 & Akaike info criterion & -5.095381 \\
Sum squared resid & 0.050329 & Schwarz criterion & -2.884928 \\
Log likelihood & 1011.904 & Hannan-Quinn criter. & -4.212994 \\
\hline
\end{tabular}

Panel C2

Dependent variabel: $\Delta \mathrm{g}$ dynamics of gini index

Dynamic regressor: economic growth(y), economic growth squared $\left(\mathrm{y}^{2}\right)$

Selected Model: ARDL $(3,1,1)$

\begin{tabular}{crrrr}
\hline \hline Variable & Coefficient & Std. Error & t-Statistic & \multirow{2}{*}{ Prob. ${ }^{*}$} \\
\hline \hline \multicolumn{5}{c}{ Long Run Equation } \\
PDRB & 8.165577 & 1.513182 & 5.396294 & 0.0000 \\
PDRB2 & -32.78052 & 6.665238 & -4.918132 & 0.0000 \\
\hline \hline \multicolumn{5}{c}{ Short Run Equation } \\
COINTEQ01 & -0.279106 & 0.086979 & -3.208876 & 0.0016 \\
D(GR(-1)) & -0.277182 & 0.108832 & -2.546891 & 0.0118 \\
D(GR(-2)) & -0.153124 & 0.083574 & -1.832202 & 0.0689 \\
D(PDRB) & 2.393618 & 1.389814 & 1.722258 & 0.0870 \\
D(PDRB2) & -37.15862 & 17.00419 & -2.185263 & 0.0304 \\
C & 0.016914 & 0.009087 & 1.861411 & 0.0646 \\
\hline \hline Mean dependent var & -0.000401 & S.D. dependent var & 0.036956 \\
S.E. of regression & 0.027634 & Akaike info criterion & -3.480246 \\
Sum squared resid & 0.117604 & Schwarz criterion & -2.367213 \\
Log likelihood & 470.7481 & Hannan-Quinn criter. & -3.031171 \\
\hline \hline
\end{tabular}

Dilihat dari hasil pengujian ARDL pada tabel 4.6 didapatkan hasil untuk provinsi pada klaster 1 ketimpangan pendapatan berpengaruh secara negatif signifikan (-12.6865) terhadap pertumbuhan ekonomi pada jangka panjang. Sedangkan pada jangka pendek ketimpangan pendapatan juga berpengaruh secara signifikan pada lag 1. Selanjutnya pada klaster 1 juga ditemukan hubungan kurva $\mathrm{U}$ diantara ketimpangan pendapatan dan pertumbuhan ekonomi (dari koefisien gini rasio kuadrat yang positif dan signifikan)

Pada klaster 2 pertumbuhan ekonomi berpengaruh secara positif signifikan ( 8.1655 ) 
terhadap ketimpangan pendapatan pada jangka panjang. Sedangkan pada jangka pendek pertumbuhan ekonomi juga berpengaruh positif namun tidak signifikan. Hal ini juga dijelaskan oleh hasil yang signifikan pada nilai masa lalunya. Sehingga kesimpulannya pada jangka pendek klaster 2 hanya dipengaruhi oleh nilai masa lalu dari gini rasio itu sendiri. Selanjutnya pada klaster 2 juga ditemukan hubungan kurva U terbalik diantara pertumbuhan ekonomi dan ketimpangan (dari koefisien pertumbuhan PDRB Per Kapita kuadrat yang negatif dan signifikan).

\section{KESIMPULAN}

Untuk melihat hubungan pertumbuhan ekonomi dan ketimpangan pendapatan di Indonesia dapat dilihat melalui klaster yang terbentuk dari kesamaan pola ekonomi tiap provinsinya. Klaster yang terbentuk ada 2 yaitu klaster 1 dengan kombinasi pertumbuhan ekonomi dan ketimpangan pendapatan yang rendah dan klaster 2 dengan kombinasi pertumbuhan ekonomi dan ketimpangan yang tinggi. Dari masing masing klaster ini dilakukan analisis kausalitas dan ekonometrik. Didapatkan hasil pada klaster 1 ketimpangan pendapatan berpengaruh secara negatif signifikan terhadap pertumbuhan ekonomi pada jangka panjang maupun jangka pendek. Sedangkan pada klaster 2 pertumbuhan ekonomi berpengaruh secara positif signifikan terhadap ketimpangan pendapatan pada jangka panjang serta pada jangka pendek hanya dipengaruhi secara signifikan oleh nilai masa lalu dari ketimpangan pendapatan itu sendiri

\section{DAFTAR PUSTAKA}

[1] Agusalim, L. (2016). Pertumbuhan Ekonomi, Ketimpangan Pendapatan dan Desentralisasi di Indonesia. KINERJA Vol. 20 No. 1, 53-68.

[2] Barro, R. (2000). Inequality and growth in a panel of countries. J. Econ. Growth , 5-32.

[3] Brida, J. G., Carrera, E. J. S., \& Segarra, V. (2019). Clustering and Regime Dynamics for Economic Growth and Income Inequality. Structural Change and Economic
Dynamics.

doi:10.1016/j.strueco.2019.09.010

[4] Castello, A. (2010). . Inequality and growth in advanced economies: an empirical investigation. J. Econ. Inequality , 293-321.

[5] Kaur, Noor K., Kaur, Usvir., \& Singh, Dr. Dheerendra., (2014). K-Medoids Clustering Algorithm - A Review. [pdf] International Journal of ComputerApplication and Technology (IJCAT).ISSN. 2349-1841 Vol. 1, Issue 1. April2014.

[6] Krishnapuram R., Joshi A., Nasraoui O., Yi L., (2001). Low-complexity fuzzy relational clustering algorithms for web mining. IEEE Transactions on Fuzzy Systems, 9, 595-607

[7] Ortega, A. (2006). Assessment of the Relationship between Income Inequality and Economic Growth: A Panel Data Analysis of the 32 Federal Entities of Mexico, 19602002. Contributions to Economic Analysis, Vol. 274, 361-381.

[8] Piketty, T. (2014). Capital in the TwentyFirst Century. Belknap Press.

[9] Wibowo, T. (2016). Ketimpangan Pendapatan dan Middle Income Trap. Kajian Ekonomi Keuangan Vol. 2 No. 2 , 112-132. 